\title{
ASSESSMENT OF DIOXINS AND FURANS EMISSIONRESULTING FROM CEMENT INDUSTRY USING UNEP TOOLKIT
}

\author{
Soliman, S. A. ${ }^{(1)}$; Gad Alla, Sohair, A. ${ }^{(2)}$; El Hashash, M. A. ${ }^{(3)}$ \\ and El Refaie, Hend, M. $^{(4)}$
}

1) Faculty of Agriculture, Alexandria University 2) Central Lab of Residue Analysis of Pesticides and Heavy Metals in Food, Agriculture Research Center, Ministry of Agriculture 3) Faculty of Science, Ain ShamsUniversity 4) General Department of Hazard Substances and Waste, Ministry of State for Environmental Affairs.

\begin{abstract}
Polychlorinated dibenzo-para-dioxins (PCDDs) and Polychlorinated dibenzo- furans (PCDFs) may be released during fuel combustion in several industries including cement production. Estimation of dioxins and furans released from four cement factories in the Red Sea region, Suez Governorate, Egypt, has been calculated. The Standardized Toolkit recommended by the United Nation Environmental Program, UNEP for Identification and Quantification of PCDD's and PCDF'srelease developed by UNEP was used. Data about incineration of hazardous waste in cement kilns are also collected. Only one plant was found to incinerate according to controlled combustion processes that apply good air pollution control system, APCS, in place. The default emission factors established by UNEP toolkit were used to estimate the PCDD's and PCDF's. Only one plant allows the use of hazardous wastes, $\mathrm{HW}$, in its fueling mixture. The calculated dioxins and furans for this plant (A) was $0.77 \mathrm{~g}$ TEQ/year into air with dioxins residue of $12.135 \mathrm{~g}$ TEQ/year. However, emission rate of other plants(B,C and D) were, 0.1165, 0.1 and0.07 $\mathrm{g}$ TEQ/year, respectively, compared with the permissible limit set by the European Union as is $0.1 \mathrm{ng}$ TEQ $/ \mathrm{Nm}^{3}$ TEQ for concentration of dioxin-like compounds in the discharged flue gas is $0.1 \mathrm{ng}$ TEQ/ $\mathrm{Nm}^{3}$ TEQ.( "EU limit value". europa.eu)
\end{abstract}

Key Words: Dioxins- Furans- Toolkits- Cement-TEQ- TCDD-HW. 
Abbreviations: $\mathrm{PCDD}=$ Polychlorinated dibenzo-para-dioxins, $\mathrm{PCDF}=$ Polychlorinated dibenzofurans, $\mathrm{y}=$ year, APCS $=$ Air Pollution Control System, HW=Hazardous Waste, TEQ $=$ Toxic Equivalent Quantity, TCDD=tetrachlorodibenzo-p-dioxin, UNEP= United Nations Environment Program

\section{INTRODUCTION}

Polychlorinated dibenzo-p-dioxins (PCDDs) (Dioxins), and polychlorinated dibenzofurans (PCDFs) (Furans) are organochlorine compounds that produced unintentionally during some anthropogenic activities such as combustion and as byproducts of industrial processes and from some other activities of the municipality. They are a class of chemical compounds widely recognized as the most ever man-made toxic chemicals, (Mansur et al., 2007). These two classes of chemicals consist of 75 chlorinated dibenzo-p-dioxin and 135 chlorinated dibenzo furan congeners respectively. The most widely studied congener is 2,3,7,8-tetrachlorodibenzop-dioxin (TCDD). This derivative, often simply called dioxin, and due to its superior toxicity it was used as the reference for toxicity of this type of compounds (US EPA, 2000 and EPA-NCEA, 1998). The general chemical structure of PCDDs and PCDFs are shown in following Figure. 


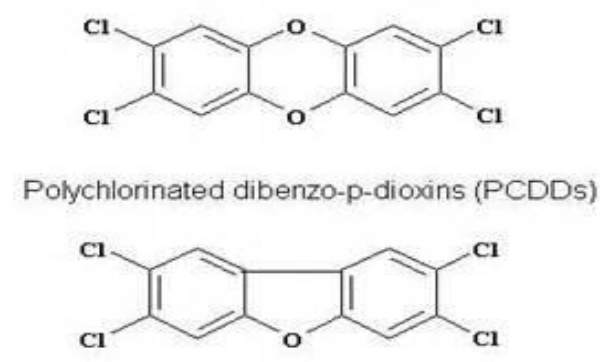

Polychlorinated dibenzofurans (PCDFs)

Physicochemically, these groups of pollutants are highly persistent in the environment resisting natural and biological degradation. They are also proved to be severely toxic to humans as well as to wild life.They migrate, through air, water, and soil, and migratory species across international boundaries and deposited far from their place of release where they bio accumulate in terrestrial and aquatic ecosystems.( Henry, E.C.; et al 1999).

Dioxins and furans formed as by-products during the manufacturing of some organochlorines, in the incineration of chlorine-containing organic substances such as polyvinyl chloride (PVC), in the chlorine bleaching of paper, and from natural sources such as volcanoes and forest fires. (Beychok,1987).

Generation of dioxins is highly dependent on temperature, retention time in the combustion process, presence of catalytic metals and fly ash particles. It has been shown that high temperature of combustion in the range of 200 to $400^{\circ} \mathrm{Cproduces}$ the highest levels of dioxins in combustion chambers (Safe, (1990). 
The International Agency for Research on Cancer (IARC) has characterized 2,3,7,8-TCDD as a "human carcinogen" (IARC, 1997). Due to the potential toxicity of dioxin-like compounds, great emphasis has been placed on policies to abate these compounds globally. (Young A.L.,et al 2005).

Due to the great international concern in protecting the human health and environment from dioxins and furans emission they were added in Annex C of the Stockholm Convention list of Persistent Organic Pollutants (POPs) where Egypt has became a signatory of the Stockholm Convention on 17/5/2002 and ratified it on 2 / 5 / 2003. According to part II in Annex C of the "Stockholm Convention on Persistent Organic Pollutants", polychlorinated di-benzo-p-dioxins and di-benzo furans, in addition to hexachlorobenzene are unintentionally formed products released during thermal processes involving organic matter and chlorine and as a result of incomplete combustion or during some chemical reactions.

Due to the high cost of analysis of the dioxins and furans and in order to assist countries as they identify sources and estimate releases of dioxins and furans, UNEP chemicals has developed a "Standardized Toolkit for Identification and Quantification of Dioxin and Furan Releases." The basic principle is to gather "activity statistics" which describe the amount of end products of a particular industrial process burnt garbage (e.g., tons of cement produced in a plant per year), and "emission factors" which describe release of PCDD/PCDF to each medium per unit of activity (e.g., $\mu \mathrm{g} I-\mathrm{TEQ} / \mathrm{ton}$ ), 
then multiplying the two to obtain the annual releases of PCDD and PCDF toxic equivalent, TEQ, (UNEP ,2005).

The "Toolkit" is designed to produce a simple and standardized methodology and accompanying database to enable assembly of consistent national and regional PCDD/PCDF inventories. It comprises an UNEPrecommended procedure for the effective compilation of source and release inventories of PCDD/PCDF. This method for the estimation of dioxins and furans compounds has been devised by UNEP and has been used by at least 15 industrialized countries(Schecter et al., 2006).

The aim of this work is to estimate the levels of dioxins and furans compounds generatedin the different media (air and residue) as the result of incineration of hazardous wastes in cement kilns locatedin the Red Sea region by applying the UNEP standardized procedures, "Toolkit" in order to help addressing the best technology for reduction and elimination of the release of such extremely hazardous pollutants.

\section{MATERIALS AND METHODS}

The estimation of PCDD/PCDF releases from four cement factories located in the Red Sea region of Egypt have been carried out using Standardized Toolkit for identification and quantification of dioxin and furan releases that was developed and recommended by UNEP.

The data collected in the framework of the project for the promotion of strategies to reduce unintentional production and release of persistent organic pollutants (POPs) in the Red Sea and Gulf of Aden-coastal zone (PERSGA), 
carried in Egypt in 2010 within the National Implementation Plan (NIP) of the Stockholm Convention on (POP's) in Egypt.

\section{DATA COLLECTION}

The selected four cement plants, designated as A, B, C and D, are located in Red Sea region. Their production rate and the level of used technology are described in Table (1). The data about incineration of hazardous wastes in these cement kilns were obtained from the official approval records of Suez Governorate. Only one plant incinerating with controlled combustion processes, and with good APCS, was allowed to incinerate hazardous wastes at annual rate of $26,966.66$ ton/ year.

Table (1):Rate of cement Production and the technology applied at the studied cement plants.

\begin{tabular}{||c|c|c|c||}
\hline $\begin{array}{c}\text { Pl } \\
\text { ant }\end{array}$ & $\begin{array}{c}\text { Production rate } \\
\text { of cementton/year }\end{array}$ & Production technology & $\begin{array}{c}\text { Hazardous } \\
\text { Wastes (HW) used } \\
\text { in incineration }\end{array}$ \\
\hline \hline $\begin{array}{c}\text { Pl } \\
\text { ant A }\end{array}$ & $\mathbf{1 0 , 0 0 0 , 0 0 0}$ & $\begin{array}{c}\text { Dry kilns } \\
\text { preheater/precalcinerESP/FF } \\
\text { temperature }<200\end{array}$ & $\begin{array}{c}\text { Incinerate } \\
\text { HW by controlled } \\
\text { combustion } \\
\text { processes, good } \\
\text { APCS }\end{array}$ \\
\hline $\begin{array}{c}\text { Pl } \\
\text { ant B }\end{array}$ & $\mathbf{2 , 3 3 0 , 8 3 0}$ & $\begin{array}{c}\text { Dry kilns } \\
\text { preheater/precalcinerESP/FF } \\
\text { temperature }<200\end{array}$ & $\begin{array}{c}\text { No } \\
\text { incinerationof } \\
\text { (HW) }\end{array}$ \\
\hline $\begin{array}{c}\text { Pl } \\
\text { ant C }\end{array}$ & $\mathbf{2 , 0 0 0 , 0 0}$ & $\begin{array}{c}\text { Dry kilns } \\
\text { preheater/precalciner ESP/FF } \\
\text { temperature }<200\end{array}$ & $\begin{array}{c}\text { No } \\
\text { incinerationof } \\
\text { (HW) }\end{array}$ \\
\hline $\begin{array}{c}\text { Pl } \\
\text { ant D }\end{array}$ & $\mathbf{1 , 4 2 4 , 2 1 6}$ & $\begin{array}{c}\text { Dry kilns } \\
\text { preheater/precalciner ESP/FF } \\
\text { temperature }<200\end{array}$ & $\begin{array}{c}\text { No } \\
\text { incinerationof } \\
\text { (HW) }\end{array}$ \\
\hline \hline
\end{tabular}

$\mathrm{APCS}=$ Air pollution control system, ESP/FF=Electrostatic precipitator or fabric filter. 
The default emission factors developed by UNEP Toolkit are based on the assumption that the waste burned leads to about $3 \%$ of fly ash and the PCDD/PCDF release associated with the disposal of bottom ash is negligible in the part that burns hazardous wastes.

The following table represents four classes of emission factors in $\mu \mathrm{g}$ $\mathrm{TEQ} / \mathrm{t}$ in air or as residue for hazardous waste incinerators based on using the UNEP Toolkit, 2005.

Table (2): UNEP estimated emission factors in $\mu \mathrm{g}$ TEQ/t $\mathrm{HW}$ burned according to the type of technology of combustion.

\begin{tabular}{|l|l|c|c|}
\hline \multirow{2}{*}{$\begin{array}{l}\text { Classification of HW incineration tech. } \\
\text { in cement kilns }\end{array}$} & \multicolumn{2}{|c|}{$\begin{array}{c}\text { Emission Factors - } \boldsymbol{\mu} \text { g TEQ/t } \\
\text { HWurned }\end{array}$} \\
\cline { 2 - 4 } & Air & Residue \\
\hline \hline 1 & $\begin{array}{l}\text { Low technology combustion, no } \\
\text { APCS }\end{array}$ & 35,000 & 9,000 \\
\hline 2 & $\begin{array}{l}\text { Controlled combustion, minimal } \\
\text { APCS }\end{array}$ & 350 & 900 \\
\hline 3 & Controlled combustion, good APCS & 10 & 450 \\
\hline 4 & $\begin{array}{l}\text { High technology combustion, } \\
\text { sophisticated } \\
\text { APCS }\end{array}$ & 0.75 & 30 \\
\hline
\end{tabular}

TEQ/t HW= Toxic Equivalent Quantity per ton of Hazardous Waste burned.

The UNEP Toolkits, 2005 also established the emission factors based on cement kilns, temperature as shown in Table (3). 
Table (3): Emission factors based on cement kilns established by UNEP Toolkits (2005).

\begin{tabular}{|l|l|c|c|}
\hline \multirow{2}{*}{$\begin{array}{c}\text { Classification of cement production } \\
\text { tech. }\end{array}$} & \multicolumn{2}{|c|}{$\begin{array}{c}\text { Emission factors - } \boldsymbol{\mu} \text { g TEQ/t of } \\
\text { cement }\end{array}$} \\
\cline { 2 - 4 } & Air & Residue \\
\hline 1 & Shaft kilns & 5.0 & $\mathrm{ND}$ \\
\hline 2 & $\begin{array}{l}\text { Old wet kilns, ESP temperature } \\
>300{ }^{\circ} \mathrm{C}\end{array}$ & 5.0 & $\mathrm{ND}$ \\
\hline 3 & $\begin{array}{l}\text { Rotary kilns, ESP/FF } \\
\text { temperature200-300 }{ }^{\circ} \mathrm{C}\end{array}$ & 0.6 & $\mathrm{ND}$ \\
\hline 4 & $\begin{array}{l}\text { Wet kilns, ESP/FF temperature } \\
<20{ }^{\circ} \mathrm{Cand} \text { all types of Dry kilns } \\
\text { preheater/precalciner, T<200 }\end{array}$ & 0.05 & $\mathrm{ND}$ \\
\hline
\end{tabular}

As can be seen, there is no emission factor for releases with residues. Typically, the dust from cement plants is reintroduced (recycled) into the kiln with the raw materials.

In this plant the fuel is used to provide the heat required to convert the kiln feed into clinker. Hot clinker discharged from the kiln drops onto the grate cooler for cooling from approximately $1350-1450{ }^{\circ} \mathrm{Cto}$ approximately $120{ }^{\circ} \mathrm{C}$. In the cooler, the quantity of cooling air required for clinker cooling is extracted from the atmosphere by different cooling fans and fed into the cooler chambers and pressurized through the cooler plate and clinker bed. The cooled clinker discharged from the cooler into the pan conveyor and then transported to the clinker storage. So an emission factor of $0.05 \mu \mathrm{g} T E Q / t$ of cement is applied where dust collector (preheater/ precalciner) temperature is held below $200{ }^{\circ} \mathrm{C}$ and the amount of cement produced is $10,000,000$ ton per 
year; therefore, we can estimate the amount of dioxins and furans released from this plant (A) into the air.

The emission factor for each class represents the best estimate (medians or means) based on measured data at existing sources with similar technology, process characteristics, and operating practices. The vast majority of emission factors are based on published data found in peer-reviewed literature or in governmental or institutional reports (UNEP Toolkit, 2005). The estimate of total Dioxins and furans release was calculated using the following equation:

\section{Dioxins and furans emission $/ \mathrm{y}(\mathrm{gm}$ TEQ/y $)=$ Emission Factor $(\mu \mathrm{g}$ TEQ/t) x Activity Rate(t/y)}

Where, activity rate is the amount of hazardous waste incinerated or the cement produced in tons per year.

\section{RESULTS AND DISCUSSION CEMENT PRODUCTION}

The principal raw materials used in cement productionare clay and limestone. Cement manufacture begins with calcination, which is the decomposition of calcium carbonate $\left(\mathrm{CaCO}_{3}\right)$ at about $900{ }^{\circ} \mathrm{C}$ to leave calcium oxide (lime) and carbon dioxide ( $\mathrm{CO} 2)$.

$$
\mathrm{CaCO}_{3} \rightarrow \mathrm{CaO}+\mathrm{CO}_{2}
$$

Afterwards, lime reacts at temperatures typically around $1,400-1,500{ }^{\circ} \mathrm{C}$ with silica, alumina, and ferric oxide to form silicates, aluminates, and ferrites 
of calcium (clinker phases). The clinker is then grounded or milled together with gypsum $\left(\mathrm{CaSO}_{4}\right)$ and other additives to produce cement. (BREF 2001).

Cement manufacturing is the source of $5 \%$ of global $\mathrm{CO}_{2}$ emissions in the world. The cement industry is a natural producer of $\mathrm{CO}_{2}$ as follow:

- $60 \%$ of emissions in cement industries are due to the transformation of raw materials at high temperatures (the decarbonation of limestone),

- $40 \%$ result from the combustion required for heatingof cement kilns to $1500^{\circ} \mathrm{C}$.

Three plants (B, C and D) out of the four studied cement plants did not use HW as fuel. However, one cement plant uses hazardous Wastes as alternative fuel, as it thought, to (i) Limit greenhouse gas emissions by reducing the use of nonrenewable natural raw materials, fossil fuels (oil, coal, etc.), (i) Diversify energy resources and reduce energy costs by limiting dependence on the market for traditional fuels, and (ii) Serve the community by recycling waste that would otherwise have to be processed and eliminated.

In the studied cement factory the cement manufacturing process generates $\mathrm{CO}_{2}$ because limestone needs to be heated to very high temperatures. This physical-chemical process of "decarbonation" produces clinker, which is then ground down. It is possible to reduce the amount of clinker in cement by using alternatives, called cement admixtures, it offer these advantages:

- a reduction in the consumption of natural, nonrenewable raw materials, 
- a reduction in the emission of greenhouse gases. Cement produced with $30 \%$ admixtures uses $230 \mathrm{~kg}$ or $27 \%$ less $\mathrm{CO} 2$ than a conventional cement produced without admixtures.

The use of alternative materials, required for production of blended cements, may be of natural origin as limestone and pozzolanic rocks or fromindustrial origin as waste products from other industries, such as slag (from steel-industry blast- furnaces) or fly ash (from coal-fired power plants). These waste products have the same hydraulic binding properties as cement clinker.

In the USA tests, carried out in the early 1990s, have indicated that higher emissions werefound for some kilns where hazardous wastes were fired (EPA 1998). However, later andmore detailed investigations have suggested that, provided combustion is good, the maincontrolling factor is the temperature of the dust collection device ESP/FF (Electrostatic precipitator or fabric filter) in the gas cleaning system (UNEP Toolkit ,2005), the plants equipped with low temperature electrostatic precipitator appear to have well controlled emissions with or without waste fuels. It thought that the raw material themselves can have a considerable influence on the emissions and the presence of high levels of organic matter in the raw materials has been associated with elevated emissions of PCDD/PCDF.( UNEP Toolkit ,2003)

Kilns usually have a device to reduce emissions of particulate matter and to capture particles, which may be valuable as cement product. The pollution control system may be a simple dust collector (cyclone), electrostatic precipitator or fabric filters. (UNEP Toolkit ,2003). 
The following Table (4)summarizes the results of some PCDDs/PCDFs measurements reviewed in the WBCSD-SINTEF (World Business Council for Sustainable Development. the Foundation for Industrial and Scientific Research), Report on the Formation and Release of POP's in the Cement Industry.

Table (4): Results of some PCDDs/PCDFs measurements reviewed in the WBCSD-SINTEF (Formation and Release of POP's in the Cement Industry).

\begin{tabular}{|c|c|c|c|c|}
\hline Country & $\begin{array}{c}\text { Use of } \\
\text { alternative } \\
\text { fuel and raw } \\
\text { materials? }\end{array}$ & $\begin{array}{c}\text { Concentration of } \\
\text { PCDD/PCDF } \\
(\mathbf{n g} \text { I-TEQ/m3)a }\end{array}$ & $\begin{array}{c}\text { No. of } \\
\text { measurements }\end{array}$ & $\begin{array}{c}\text { Emission } \\
\text { factor( } \boldsymbol{\mu g} \\
\text { I-TEQ/t } \\
\text { cement)a }\end{array}$ \\
\hline \hline Canada & Yes & $0.0054-0.057$ & 30 & \\
\hline Egypt & Yes & $<0.001$ & 3 & \\
\hline Europe & Yes & $<0.001-0.163$ & 230 & $<0.001-5$ \\
\hline Germany 2001 & Yes & $<0.065$ & 106 & \\
\hline
\end{tabular}

PCDD/PCDF analysis is carried out using High Resolution Gas Chromatography/ High resolution Mass Spectrometry (HRGC/HRMS), a very complicated and costly measurement. On the other hand, the use of the UNEP Toolkit to calculate preliminary figures of dioxins and furans emission offer a reasonable way to do such estimation where reliable sophisticated laboratories are lacking. This is the case here and as such the using the UNEP Toolkit offer a trustful mean to get proper acceptable and internationally ideas and estimates. 


\section{HAZARDOUS WASTES INCINERATION IN CEMENT KILNS:}

Any chlorine input in the presence of organic materials may potentially cause formation of polychlorinated dibenzo-para-dioxins (PCDDs) and polychlorinated dibenzofurans (PCDFs) during the combustion processes, (Draft Guidelines on BAT and BEP 2004). These PCDDs and PCDFs can be formed in/after the preheater and in the air pollution control device if chlorine and hydrocarbon precursors from the raw materials are available in sufficient quantities (Guidelines on BAT and BEP 2007).

The use of HWs as fuel in the selected cement factory was identified from the official records of Governorate and noticed during field visits. The used HWs include wastes and residues of which are solvents and other volatile hydrocarbons, paints and dyes, chemicals including pesticides, herbicides, and other halogenated chemicals, pharmaceutical products, batteries, fuels, oils and other lubricants, as well as goods containing heavy metals etc.. Typically hazardous waste is burned either in special technology incinerators or in rotary kiln type furnaces. Solid hazardous waste is introduced into a refractory lined rotary kiln via a feed chute. High calorific liquid as well as sludge waste are atomized in a burner or combustion lance located in the front wall of the rotary kiln.

The data collected from the studied factory which incinerates hazardous wastes in cement kilns in Suez Governorate indicated that it uses controlled combustion processes with, good APCS, with annual HW burned of $26,966.66$ ton/ year 
These default emission factors are based on the assumption that the waste burned leads to about $3 \%$ of fly ash and the PCDD/PCDF release associated with the disposal of bottom ash is negligible.

After reviewing the data regarding the activity rates of Hazardous Waste incineration and the cement production, the amounts of dioxins and furans compounds from the company that incinerate hazardous wastes (plant A) were calculated and illustrated in Table (5).

Table (5): The calculated amounts of dioxins and furans emitted from the plant (A) incinerating HWs.

\begin{tabular}{|c|c|c|c|c|}
\hline \multirow{2}{*}{ Plant } & \multirow{2}{*}{$\begin{array}{c}\text { Production rate } \\
\text { of cement } \\
\text { (ton/year) }\end{array}$} & \multirow{2}{*}{$\begin{array}{c}\text { The amount of HW } \\
\text { burned (ton/ year) }\end{array}$} & \multicolumn{2}{|c|}{$\begin{array}{c}\text { Emission of dioxins \& } \\
\text { furans (g TEQ/year) }\end{array}$} \\
\cline { 4 - 5 } & & & Air & Residue \\
\hline \multirow{2}{*}{ Plant A } & $10,000,000$ & 26966.66 & $\begin{array}{c}0.5+0.27 \\
=0.77\end{array}$ & 12.135 \\
\hline Plant B & $2,330,830$ & Not found & 0.1165 & Not found \\
\hline Plant C & $2,000,00$ & Not found & 0.1 & Not found \\
\hline Plant D & $1,424,216$ & Not found & 0.07 & Not found \\
\hline
\end{tabular}

This result indicates that the high emissions from plant A (0.77 g TEQ/y to air and $12.135 \mathrm{~g} \mathrm{TEQ} / \mathrm{y}$ to residue) are due to the large amount of cement produced per year $(10,000,000$ ton/y) which represents about $63.5 \%$ of the total annual production of cement in the Suez Governorate (PERSGA survey February - 2010) as shown in fig. (1). 


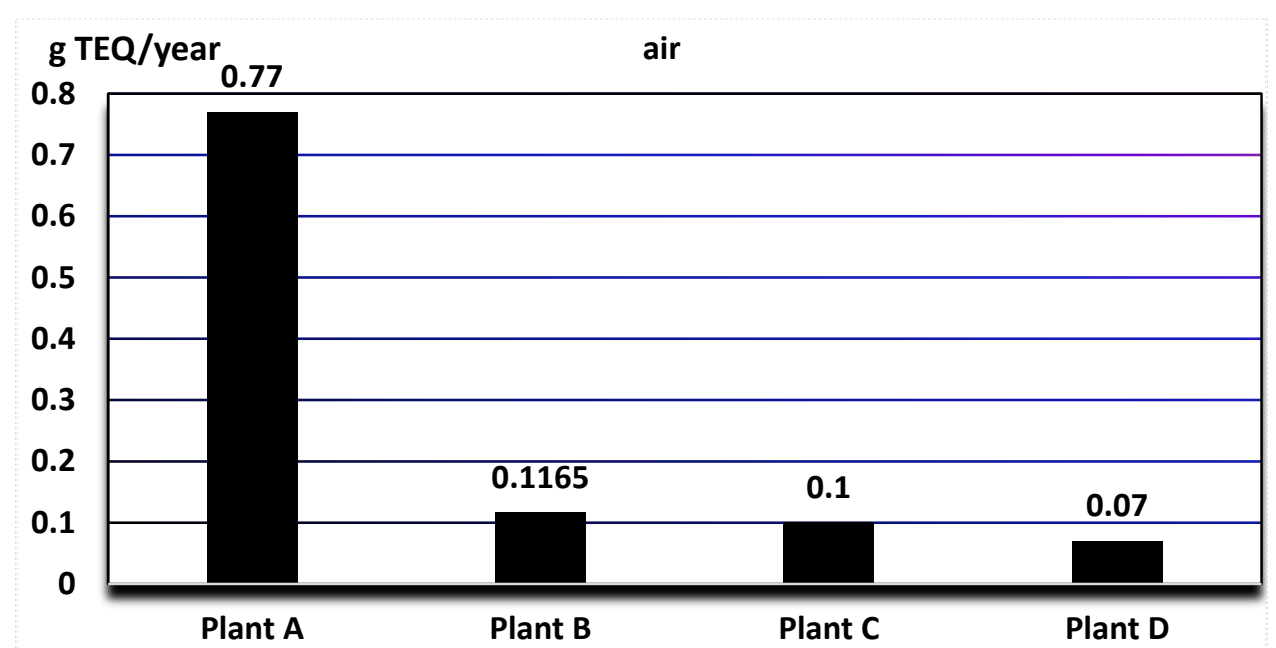

Fig. (1): Analysis of emission of dioxins and furans into air in cement plants at Suez Governorate

\section{REFERENES}

Beychok, Milton R. (1987). "A data base for dioxin and furan emissions from refuse incinerators". Atmospheric Environment 21 (1): 29-36. doi:10.1016/0004-6981(87)90267-8.

BREF (2001): Integrated Pollution Prevention and Control (IPPC) Manufacturing Industries. 12/ 2001. European Commission, Technologies for Sustainable Development, European IPPC Bureau, Seville, Spain.

EPA-NCEA, 1998 Dioxin and Related Compounds - National Center for Environmental Assessment. http://www.epa.gov/ncea/dioxin.htm.

Guidelines on Best AvailableTechniques and provisional guidanceon Best Environmental Practicesrelevant to Article 5 and Annex Cof the Stockholm Convention onPersistent Organic Pollutants2007, Geneva, Switzerland. 
Henry, E.C.; Kende, A.S.; Rucci, G.; Totleben, M.J.; Willey, J.J.; Dertinger, S.D.; Pollenz, R.S.; Jones, J.P.;Gasiewicz, T.A. (1999): Flavone antagonists bind competitively with 2,3,7,8-tetrachlorodibenzo-pdioxin (TCDD) to the aryl hydrocarbon receptor but inhibit nuclear uptake and transformation. Mol. Pharmacol, 55: 716-725.

IARC, (International Agency for Research on Cancer) (1997): Monographs on the evaluation of carcinogenic risks to humans. Polychlorinated dibenzo-p-dioxins and polychlorinated dibenzofurans. Vol. 69. World Health Organization.

Mansur R.Azari , Fatema Falaki , and Mohammad Reza Masoudi Nejad, (2007): Assessment of Dioxin-Like Compounds Released from Iranian Industries and Municipalities, Tanaffos (2007) 6(3), 59-64 @ 2007 NRITLD, National Research Institute of Tuberculosis and Lung Disease, Iran.

National implementation plan of the Stockholm convention on persistent organic pollutants (pops), Project No:(GEF/EGY/02/022) Step 2 Report 2004.

Safe S.H. (1990). Polychlorinated biphenyls (PCBs), dibenzo-p-dioxins (PCDDs), dibenzofurans (PCDFs), and related compounds: environmental and mechanistic considerations which support the development of toxic equivalency factors (TEFs). Crit. Rev. Toxicol. 21:51-88.

Schecter A., Birnbaum L, Ryan J. J, Constable J. D; Birnbaum; Ryan; Constable (2006). "Dioxins: an overview" .Environ. Res., 101(3):419-28.

Schettler, T, M. D, MPH, J., Stein M. D, F.,Reich Psy D, M.Valenti (2000). "In Harm's Way: Toxic Threats to Child Development" A Report by the Greater Boston Physicians for Social Responsibility.

UNEP 2005, 2003. Standardized toolkit for identification andquantification of Dioxin and Furan releases. Prepared byUNEP Chemicals, Geneva, Switzerland. 
Survey Report of the Project of Promotion of Strategies to Reduce Unintentional Production of POPs in the Red Sea and Gulf of Aden (PERSGA), 2 - 2010,

(eeaa.gov.eg).

US EPA, September 2000, Dioxin Re-Assessment "Draft Exposure and Human Health Reassessment of 2,3,7,8- Tetrachlorodibenzo-pDioxin (TCDD) and Related Compounds".

Young A.L., Regens,J. L. (2005). Serum TCDD levels and health effects from elevated exposure: Medical and scientific evidence. Environmental Science and Pollution Research Vol. (12) P.1-4. 


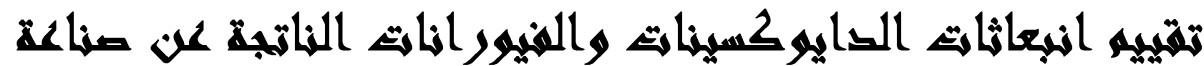

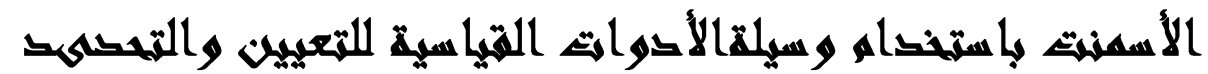

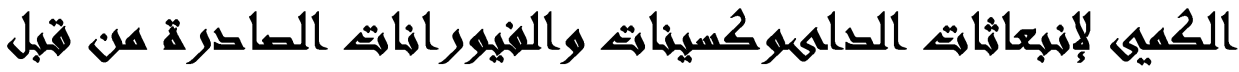

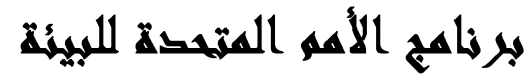

[7]

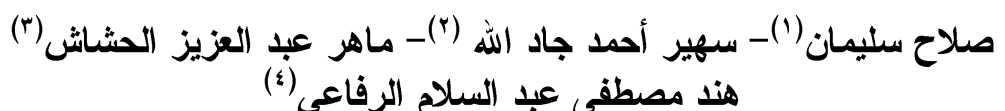

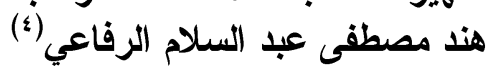

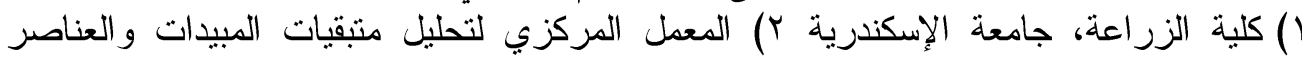

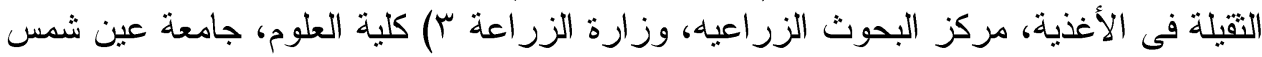

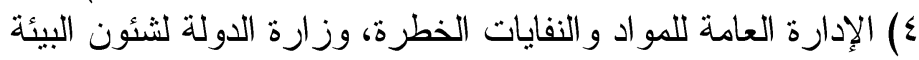

\section{المستخلص}

إن مركبات عديد الكلور ثنائي البنزين سبار ا- دايوكسين ومركبات عديد الكلور ثنائي البنزين

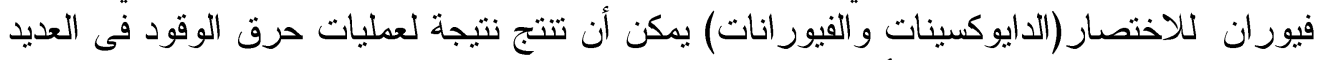

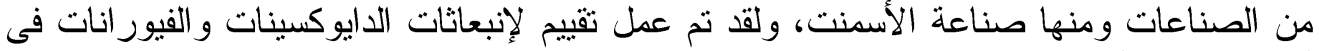

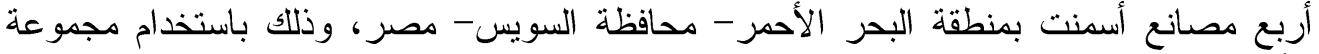

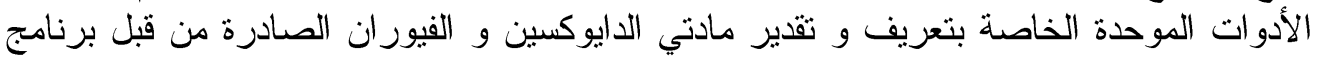

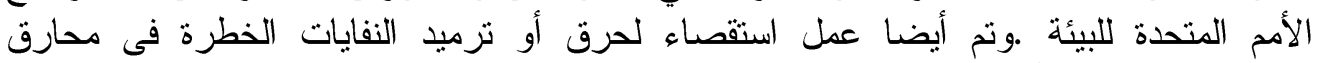

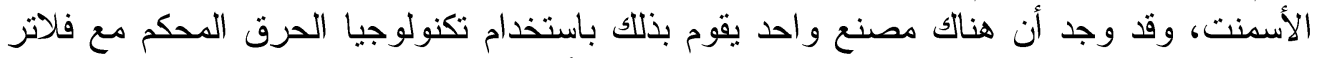

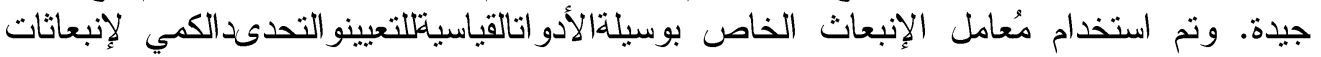

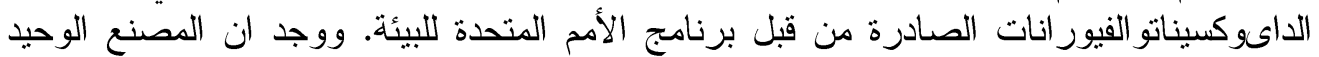

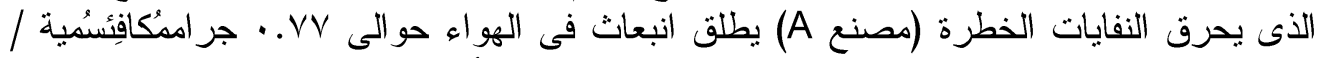

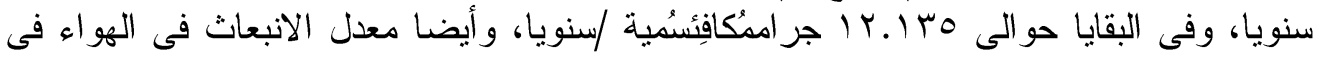

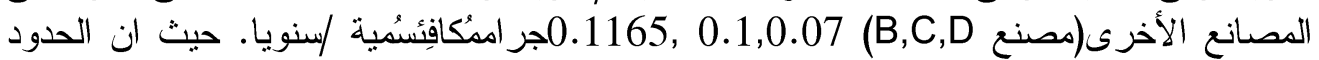

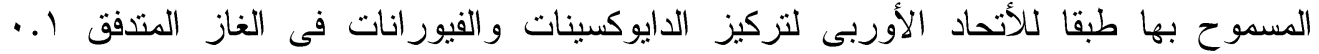

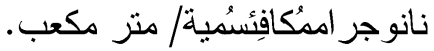

